Available online at:

http://journal.unila.ac.id/index.php/tropicalsoil

DOI: $10.5400 /$ jts.2019.v24i1.33

\title{
Formulation of Biochar Based Soil Amendment for Improvement of Upland Acidic Soil in East Lampung: Soil Properties and Maize (Zea mays) Yield
}

\author{
Neneng Laela Nurida* and Jubaedah \\ ${ }^{1}$ Soil Research Institute, Jl. Tentara Pelajar No 12 Bogor, Indonesia \\ *e-mail: lelanurida@yahoo.com
}

Received July 16, 2018; Revised December 28, 2018; Accepted January 3, 2019

\begin{abstract}
Many of soil amendment formulations (as biochar based) have been tested in Indonesian Soil Research Institute greenhouse experiments to improve its effectiveness in soil, although field experiments are still needed to measure its effectiveness on field scale. The objectives of this research are to study biochar-based soil amendment formulation with different ways of application in improving soil properties and crop yield of upland acidic soil. The research was conducted in Taman Bogo Research Station, East Lampung during three planting seasons, from January 2013 until January 2014. The study was arranged in a split plot design with 3 replications. The main plot was 3 types of soil amendment formulas namely SP50, SP75 and KS50. The subplot was the biochar-based soil amendment application ways (7.5 $\mathrm{Mg} \mathrm{ha}^{-1}$ per planting seasons), consisting of gradual application to soil namely three times of 3 planting seasons (2.5-2.5-2.5 $\left.\mathrm{Mg} \mathrm{ha}^{-1}\right)$ and two times of 3 planting seasons (5.0-2.5-0 $\left.\mathrm{Mg} \mathrm{ha}^{-1}\right)$, and single application in 3 planting seasons (7.5-0-0 $\left.\mathrm{Mg} \mathrm{ha}^{-1}\right)$. The plant indicator used was maize (Zea mays), i.e. Bisma variety. The parameters measured were soil physical and chemical properties, and maize yield. The results showed that during three planting seasons, the three types of soil amendment formulas showed no effect on soil physical properties (Bulk density/BD and available water pores/AWP), soil chemical properties ( $\mathrm{pH}$, organic $\mathrm{C}, \mathrm{K}^{+}, \mathrm{Ca}^{2+}$ and $\left.\mathrm{Al}^{3+}\right)$, and maize yield. Gradual application of biochar in two times (5.0-2.5-0 $\left.\mathrm{Mg} \mathrm{ha}^{-1}\right)$ and single time (7.5-0-0 Mg ha$\left.{ }^{1}\right)$ resulted in more effects and consistently improved AWP, soil chemical properties, and dry weight of grain during 3 planting seasons compared to the application of 3 times in 3 planting seasons $\left(2.5-2.5-2.5 \mathrm{Mg}^{-1}\right)$. The yield of maize was 3.11-5.23 $\mathrm{Mg} \mathrm{ha}^{-1}$ per season or it was increased on average $291 \%$ during three planting seasons. Biochar application at single time (at the beginning of the season at the rate of $7.5-0-0 \mathrm{Mg}^{-1}$ ) provided positive residual effects on both soil and crop in upland acidic soil of East Lampung.
\end{abstract}

Keywords: biochar, compost, formulation, soil amendment, upland acidic soil

\begin{abstract}
ABSTRAK
Berbagai formula pembenah tanah berbahan baku biochar dan kompos telah diuji di rumah kaca Balai Penelitian tanah untuk meningkatkan efektivitasnya di tanah namun demikian masih diperlukan pengujian di lapangan. Penelitian ini bertujuan untuk menguji formula pembenah tanah berbahan baku biochar pada berbagai cara pemberian dalam memperbaiki sifat tanah di lahan kering masam. Penelitian dilakukan di Kebun Percobaan (KP) Taman Bogo, Lampung Timur selama tiga musim tanam yaitu Januari 2013-Januari 2014. Penelitian ini menggunakan rancangan petak terpisah (split plot) dengan 3 ulangan. Petak utama adalah 3 jenis formula pembenah tanah yaitu SP50, SP75 dan KS50) dan anak petak adalah cara aplikasi formula pembenah tanah biochar (7,5 Mg ha-1/3 musim tanam) yaitu bertahap tiga kali (2,52,5-2,5 $\left.\mathrm{Mg} \mathrm{ha}^{-1}\right)$, bertahap dua kali (5,0-2,5-0 $\mathrm{Mg} \mathrm{ha}^{-1}$, dan sekaligus (7,5-0-0 Mg ha-1). Tanaman indikator adalah jagung varietas Bisma, sedangkan parameter yang diamati adalah sifat fisik dan kimia tanah serta hasil jagung. Hasil penelitian menunjukkan bahwa selama tiga musim tanam, ketiga jenis formula tidak berpengaruh terhadap sifat fisik tanah (bulk density (BD) dan dan pori air tersedia (PAT), sifat kimia tanah ( $\mathrm{pH}, \mathrm{C}$-organik, $\mathrm{K}=<\mathrm{Ca}^{2+}$ dan $\mathrm{Al}^{3+}$ ) serta hasil jagung. Pemberian secara bertahap (5,0-2,5-0 $\left.\mathrm{Mg} \mathrm{ha}^{-1}\right)$ dan sekaligus (7,5-0-0 $\mathrm{Mg} \mathrm{ha}^{-1}$ ) lebih efektif dan konsisten meningkatkan PAT, sifat kimia tanah dan hasil jagung selama tiga musim tanam dibandingkan dengan cara bertahap $(2.5-2.5-2.5 \mathrm{Mg}$ $\mathrm{ha}^{-1}$ ). Hasil pipilan kering jagung yang dihasilkan pada aplikasi formula pembenah tanah biochar berkisar 3,11-5,23 Mg
\end{abstract}

J Trop Soils, Vol. 24, No. 1, 2019: 33-41

ISSN 0852-257X; E-ISSN 2086-6682 
ha $^{-1}$ per musim atau terjadi peningkatan rata-rata $291 \%$ selama tiga musim tanam. Pemberian ketiga jenis formula biochar sekaligus di awal memberikan efek residu yang menguntungkan bagi tanah dan tanaman di lahan kering masam Lampung Timur.

Kata kunci: Biochar, formulasi, kompos, lahan kering masam, pembenah tanah

\section{INTRODUCTION}

The purpose of utilization of land resources in order to expand agricultural land has been started by optimization of sub-optimal land such as upland acidic soil. Based on the assessment of land capability, the utilization of upland acidic soil is very potential with the total area of 107.36 million ha, in which 98.3 million ha are arable land that suitable for agricultural development and only 33.6 million ha are potential for developing annual crops (BBSDLP 2014). The main constraints of upland acidic soil for food crop production are high soil acidity or low soil $\mathrm{pH}$, low organic $\mathrm{C}$, base cations $\left(\mathrm{Ca}^{2+}, \mathrm{Mg}^{+}, \mathrm{K}^{+}\right)$, soil cation exchange capacity/CEC (Rochayati and Dariah 2012) and poor available $P$ (Singh et al. 2003). Thus, plants are not optimally grown. The soil physical properties of upland acidic soil also can be acting as constraints in crop production, such as high soil bulk density, and low soil total pores, soil permeability, and soil water availability (Soelaeman and Haryati 2012). Previous studies showed that in acidic soil, without soil amelioration, maize productivity was low, i.e. $1 \mathrm{Mg}$ ha $^{-1}$ (Nurida 2015, Soelaeman et al. 2017, Maswar and Soelaeman 2016, Wigena and Andriati 2016), even may no yield at all (Cornelissen et al. 2018). Therefore, these acidic soils need to be rehabilitated in order to support crop production.

Biochar from agricultural waste is one of the soil amendments that is already proven to enhance soil pH (Jeffery et al. 2011; Spokas et al. 2012; Nurida et al. 2014; Zhu et al. 2014), water retention (Atkinson et al. 2010; Sutono and Nurida 2012; Suwardji et al. 2012; Shaaban et al. 2013), nutrient retention (Haefele et al. 2011; Sukartono and Utomo 2012; Nurida et al. 2014; Hale et al. 2013) and thus increase crop productivity (Asai et al. 2009; Nurida et al. 2014; Dariah et al. 2013). The results of MetaAnalysis showed that biochar is more effective when applied to acidic soils, degraded and sandy soils (Jeffery et al. 2011; Crane Droesch et al. 2013). The current problems of biochar application are high amount of feedstock required, low nutrient content in biochar, and also variation of the characteristics and quality of the feedstock to produce biochar. Therefore, biochar formulation is required that its effectivity on soil may improve. Biochar enriched with compost might be one of the ways to improve biochar quality in order to improve upland acidic soil properties faster and more effective.

Animal manure is commonly used for soil amendment or nutrient sources. Nutrient availability from manure depends on organic material and its decomposition process. $\mathrm{N}, \mathrm{P}$ and $\mathrm{K}$ content in manure can be in the range of 0.53 to $1.50 \%$; 0.10 $0.93 \%$ and $0.30-0.93 \%$, respectively (Tan 1993). However, Japanese study showed that composting of cow manure decreased $\mathrm{N}$ concentration up to 10-25\% (Schulz et al. 2013). Several studies have shown that manure mixed with biochar resulted in a positive impact on plant growth and yield (Kammann et al. 2016, Schmidt et al. 2015, Schulz et al. 2013). Biochar-compost applications may improve $\mathrm{N}$ and $P$ availability in soil compared to biochar application only (Kammann 2015; Agegnehu et al. 2016; Schulz et al. 2014).

Many types of soil amendment formulations (biochar and manure or compost based) such as SP50, SP75, KK50, KK75, KS50 and KS75 have been tested in the greenhouse experiments of Soil Research Institute and are known to have comparative advantages (Nurida et al. 2009; Nurida et al. 2013). However, to obtain the most effective soil amendment formula, it is necessary to test it on the field simultaneously. The objective of the study was to investigate biochar-based soil amendment formulation in different ways of application to improve soil properties of upland acidic soil to support crop (maize) productivity.

\section{MATERIALS AND METHODS}

\section{Research Design}

The study was conducted in the Research Station of Taman Bogo (Kebun Percobaan Taman Bogo), Taman Bogo Village, Purbolinggo Sub District, East Lampung $\left(05^{\circ} 00.406^{\prime} \mathrm{S}\right.$; $\left.105^{\circ} 29.405^{\circ} \mathrm{E}\right)$ and the research was done for 3 planting seasons namely January-April 2013 (planting season 1), May-August 2013 (planting season 2) and October 2013-January 2014 (planting season 3). The soil type in the Research Station of Taman Bogo is Typic Kanhapludults. The study was arranged in a split plot design with 3 replications. The main plots were 3 types of soil amendment that combine rice husk (SP) and oil palm shell (KS) 
Table 1. Characteristics of biochar-based soil amendment.

\begin{tabular}{lcccc}
\hline \multicolumn{1}{c}{ Parameter } & Unit & SP50 & SP75 & KS50 \\
\hline $\mathrm{pH} \mathrm{H} \mathrm{H}_{2} \mathrm{O}$ & & 7.1 & 7.7 & 7.4 \\
Total-C & $\%$ & 32.07 & 32.82 & 41.83 \\
Total-N & $\%$ & 1.70 & 1.47 & 1.83 \\
Water content & $\%$ & 10.24 & 8.69 & 10.07 \\
$\mathrm{C} / \mathrm{N}$ ratio & & 22 & 25 & 26 \\
$\mathrm{P}_{2} \mathrm{O}_{5}$ & $\%$ & 1.14 & 0.91 & 1.09 \\
$\mathrm{~K}_{2} \mathrm{O}$ & $\%$ & 1.14 & 0.90 & 1.10 \\
$\mathrm{CaO}$ & $\%$ & 1.89 & 1.50 & 1.82 \\
$\mathrm{MgO}$ & $\%$ & 0.68 & 0.57 & 0.70 \\
\hline
\end{tabular}

Note: SP50: 50\% rice husk biochar and 50\% compost; SP75: $75 \%$ rice husk biochar and 25\% compost; KS50: $50 \%$ oil palm biochar and $50 \%$ compost.

biochar with manure compost by $50 \%$ and $75 \%$ proportion in weight (SP50, SP75 and KS50). The subplot was the rate of biochar-based soil amendment (7.5 $\mathrm{Mg} \mathrm{ha}^{-1}$ per 3 planting seasons), which gradually applied to soil, namely three times of 3 planting seasons $\left(2.5-2.5-2.5 \mathrm{Mg} \mathrm{ha}^{-1}\right)$, two times of 3 planting seasons $\left(5.0-2.5-0 \mathrm{Mg} \mathrm{ha}^{-1}\right.$, and a single time in 3 planting seasons (7.5-0-0 $\left.\mathrm{Mg} \mathrm{ha}^{-1}\right)$. Overall, the rate of soil amendment application was $7.5 \mathrm{Mg} \mathrm{ha}^{-1}$ for 3 planting seasons.

\section{Application of Soil Amendment and Fertilizer}

Soil amendment formula tested in the curent study was set up by Indonesian Soil Research Institute from greenhouse activity, which resulted 3 best formula (Nurida et al. 2013). The characteristics of the soil amendment tested are presented in Table 1. Biochar based soil amendment was applied to soil 2 weeks before planting. The application were carried out in three ways, i.e. 2.52.5-2.5 $\mathrm{Mg} \mathrm{ha}^{-1} ; 5-2.5-0 \mathrm{Mg} \mathrm{ha}^{-1}$, and 7.5-0-0 Mg $\mathrm{ha}^{-1}$. The treatment of $2.5-2.5-2.5 \mathrm{Mg} \mathrm{ha}^{-1}$ indicated that $2.5 \mathrm{Mg} \mathrm{ha}^{-1}$ of biochar based soil amendment were applied in each of planting season ( 3 times at a whole 3 planting seasons), meanwhile the treatment of 5-2.5-0 $\mathrm{Mg} \mathrm{ha}^{-1}$ indicated that $5 \mathrm{Mg}$ ha $^{-1}$ of biochar based soil amendment were applied in the first planting season and $2.5 \mathrm{Mg} \mathrm{ha}^{-1}$ were applied in the second planting season (twice in a whole 3 planting seasons, without any addition in the third planting season), and the treatment of 7.5$0-0 \mathrm{Mg} \mathrm{ha}^{-1}$ indicated that $7.5 \mathrm{Mg} \mathrm{ha}^{-1}$ of biochar based soil amendment were applied in the first planting season, and no application of soil amendment at the second and third planting seasons. Maize (Zea mays L.), i.e. Bisma variety was planted in each treated plot with the spacing of $40 \mathrm{~cm} \times 75 \mathrm{~cm}$.
About $300 \mathrm{~kg} \mathrm{ha}^{-1}$ Urea and $200 \mathrm{~kg} \mathrm{ha}^{-1}$ Phonska were applied, respectively. Phonska (NPK fertilizer) was applied when planting the maize, meanwhile Urea fertilizer was applied at 21 and 42 days after planting (DAP).

\section{Soil Sampling and Analysis}

Soil sampling was carried out before planting (one soil sample) and 1 week before harvesting (all treated plots). Composite soil samples for soil chemical properties analysis and undisturbed soil samples for soil physical properties analysis were taken at $0-20 \mathrm{~cm}$ depth. A composite sampling was performed by using 1-inch diameter of soil auger at 5 different spots in 1 plot then mix the samples into $0.5 \mathrm{~kg}$ of soil sample. The undisturbed soil samples were taken using a ring sampler with $7.5 \mathrm{~cm}$ diameter and $4 \mathrm{~cm}$ height. The parameters measured in the current study were: (1) the characteristics of biochar based soil amendment including $\mathrm{pH} \mathrm{H}_{2} \mathrm{O}$, total $\mathrm{C}$ (Loss on Ignition method), total $\mathrm{N}$ (Kjeldahl method), $\mathrm{P}_{2} \mathrm{O}_{5}, \mathrm{~K}_{2} \mathrm{O}, \mathrm{CaO}$ and $\mathrm{MgO}$ (Wet Digestion method using $\mathrm{HNO}_{3}$ and $\mathrm{HClO}_{4}$ ), cation exchange capacity (CEC) $\left(\mathrm{NH}_{4} \mathrm{OAc} \mathrm{pH} 7\right.$ method) and Fe content (Dithionate Acid method, AAS). The characteristics of biochar based soil amendment were analyzed before its application on soil, (2) soil properties including bulk density and total porosity (Gravimetric method), $\mathrm{pH} \mathrm{H}_{2} \mathrm{O}, \mathrm{CEC}\left(\mathrm{NH}_{4} \mathrm{OAc} \mathrm{pH} 7\right)$, organic $\mathrm{C}$ (Walkley and Black), total $\mathrm{N}$ (Kjeldahl method), available $\mathrm{P}$ (Bray method), total $\mathrm{K}(\mathrm{HCl} 25 \%)$ and $\mathrm{Al}^{3+}$ (all soil samples were taken 1 week before harvesting), and 3) dry weight of maize grains.

\section{Data Analysis}

All data were statistically analyzed using analysis of variance (ANOVA) or diversity test at significance level of $95 \%$. To see the effects of significant differences among the variables due to treatments, Duncan Multiple Range Test (DMRT) was performed at significance level of 5\%.

\section{RESULTS AND DISCUSSION}

\section{Soil Physical Properties}

The results of initial soil analysis showed that the soil physical properties of the research site are afairly high bulk density (BD), i.e. $1.32-1.47 \mathrm{~g} \mathrm{~cm}^{-}$ ${ }^{3}$, total pore space (TPS) ranges from $42.2-47.8 \%$, aeration pores (AP) are 12.2-16.0\% (v/v) which are categorized as moderate, and available water pores (AWP) are low to moderate $(6.6-7.1 \%(\mathrm{v} / \mathrm{v}))$ indicating that the water availability is a constraint 
Table 2. Bulk density and available water pores of upland acidic soil at KP Taman Bogo applied with biochar-based soil amendment formulation during three planting seasons.

\begin{tabular}{lcccccc}
\hline \multirow{2}{*}{ Treatments } & \multicolumn{3}{c}{ Bulk Density/BD $\left(\mathrm{g} \mathrm{cm}^{-3}\right)$} & \multicolumn{3}{c}{ Water available pores /WAP $(\% \mathrm{v} / \mathrm{v})$} \\
\cline { 2 - 7 } & PS 1 & PS 2 & PS 3 & PS 1 & PS 2 & PS 3 \\
\hline Type of formulation & & & & & & \\
SP50 & $1.42 \mathrm{~A}$ & $1.27 \mathrm{~A}$ & $1,41 \mathrm{~A}$ & $8.22 \mathrm{~A}$ & $8.18 \mathrm{~A}$ & $10.69 \mathrm{~A}$ \\
SP75 & $1.42 \mathrm{~A}$ & $1.23 \mathrm{~A}$ & $1,39 \mathrm{~A}$ & $9.33 \mathrm{~A}$ & $8.83 \mathrm{~A}$ & $11.48 \mathrm{~A}$ \\
KS50 & $1.44 \mathrm{~A}$ & $1.22 \mathrm{~A}$ & $1,42 \mathrm{~A}$ & $8.71 \mathrm{~A}$ & $8.25 \mathrm{~A}$ & $11.28 \mathrm{~A}$ \\
Application way & & & & & & \\
$0 \mathrm{Mg} \mathrm{ha}^{-1}$ & $1.46 \mathrm{a}$ & $1.27 \mathrm{a}$ & $1.43 \mathrm{a}$ & $7.02 \mathrm{~b}$ & $7.02 \mathrm{~b}$ & $9.66 \mathrm{~b}$ \\
$7.5 \mathrm{Mg} \mathrm{ha}^{-1}(2.5-2.5-2.5)$ & $1.45 \mathrm{a}$ & $1.26 \mathrm{a}$ & $1.41 \mathrm{a}$ & $7.91 \mathrm{~b}$ & $8.13 \mathrm{~b}$ & $11.16 \mathrm{a}$ \\
$7.5 \mathrm{Mg} \mathrm{ha}^{-1}(5.0-2.5-0)$ & $1.45 \mathrm{a}$ & $1.20 \mathrm{a}$ & $1.42 \mathrm{a}$ & $10.23 \mathrm{a}$ & $10.02 \mathrm{a}$ & $11.79 \mathrm{a}$ \\
$7.5 \mathrm{Mg} \mathrm{ha}^{-1}(7.5-0-0)$ & $1.40 \mathrm{a}$ & $1.23 \mathrm{a}$ & $1.39 \mathrm{a}$ & $9.74 \mathrm{ab}$ & $8.52 \mathrm{ab}$ & $12.00 \mathrm{a}$ \\
\hline
\end{tabular}

Note: the same numbers followed by different letters in the same treatment group indicated significantly different based on DMRT at 5\% significance level. PS: Planting season.

for plant growth. The results indicated that the soil at Taman Bogo need to be improved in order to support maize production. During the three planting seasons, the results showed that the three types of biochar-based soil amendment SP50, SP75 and KS50 did not affect soil physical properties significantly. The soil bulk density (BD) and soil available water pores (AWP) were not significantly different among the three types of soil amendment applications (Table 2). Compared to control, the application of biocharbased soil amendment was significantly increased AWP but did not affect soil BD (Table 2). The formulations of biochar-based soil amendment from different feedstock (SP and KS) and proportions $(50 \%$ and $75 \%)$ were able to increase soil available water pores in upland acidic soil.

The different ways of application of biocharbased soil amendment (at once in the first season or gradually two or three times duirng the three planting seasons) at $7.5 \mathrm{Mg} \mathrm{ha}^{-1}$ did not decrease soil BD during three planting seasons. In the first planting season, the dose of soil amendment applied was $2.5 \mathrm{Mg} \mathrm{ha}^{-1}, 5.0 \mathrm{Mg} \mathrm{ha}^{-1}$ and $7.5 \mathrm{Mg} \mathrm{ha}^{-1}$, but no effect on soil BD was shown in the study. In the second planting season, additional soil amendment (in the gradual application) and residual effects (in application at once in a time) also showed no effect on soil BD. Application of soil amendment containing biochar and compost at $7.5 \mathrm{Mg} \mathrm{ha}^{-1}$ was not effective in lowering soil BD. Meanwhile, the application of SP50, SP75 and KS50 formulas at doses of $7.5 \mathrm{Mg} \mathrm{ha}^{-1}$, both gradually and at one time application were able to increase available water pores, especially after three planting seasons (Table 2 ). The gradual application (5.0-2.5-0 $\left.\mathrm{Mg} \mathrm{ha}^{-1}\right)$ and once in a time application (7.5-0-0 $\left.\mathrm{Mg} \mathrm{ha}^{-1}\right)$ were more effective and consistent in increasing available water pores compared to the gradual application (2.5-2.5-2.5 $\left.\mathrm{Mg} \mathrm{ha}^{-1}\right)$. High application doses (5.0 and $7.5 \mathrm{Mg} \mathrm{ha}^{-1}$ ) at the beginning of planting season would have more stable effect, however, $2.5 \mathrm{Mg}$ ha $^{-1}$ dose application was considered too low to affect the soil. Although, after three planting seasons, the three ways of application were very beneficial for water holding capacity of the upland acid soil.

There was no effect on soil BD was observed after application of $7.5 \mathrm{Mg} \mathrm{ha}^{-1}$ biochar-based soil amendment, which may cause by high content of clay in the soil of KP Taman Bogo (36-38\%). The application of biochar-based soil amendment during three planting seasons was also considered as shortterm application that did not affect the soil physical properties. The studies of Basso et al. (2013) and Kammann et al. (2015) showed significant effects on $\mathrm{BD}$ of sandy soil amended biochar. Quin et al. (2014) indicated that biochar application is more effective on sandy soil than clay-rich soil. In addition, Laird et al. (2010) found that BD decreased due to biochar addition after 500 days of application.

\section{Soil Chemical Properties}

The results of initial soil analysis (before treatment) showed that the soil in the research site is characterized by low $\mathrm{pH}\left(\mathrm{pH} \mathrm{H}_{2} \mathrm{O} 4.17\right)$ and very low organic $\mathrm{C}$ content $(0.9 \%)$. Furthermore, the soil CEC is only $4.98 \mathrm{cmol}(+) \mathrm{kg}^{-1}$, which is categorized very low. After three planting seasons, the soil $\mathrm{pH}$ increased and $\mathrm{Al}^{3+}$ content decreased due to biocharbased soil amendment application. The three types of biochar-based soil amendment formulas contained $50 \%$ and $75 \%$ of biochar, so the effect on soil $\mathrm{pH}$ is not significantly different among the formulas, 
Table 3. $\mathrm{pH}$, Organic $\mathrm{C}$ and $\mathrm{K}^{+}$content of upland acid soil in KP Taman Bogo applied with biochar-based soil amendment formulas during three planting seasons.

\begin{tabular}{|c|c|c|c|c|c|c|c|c|c|}
\hline \multirow{2}{*}{ Treatments } & \multicolumn{3}{|c|}{$\mathrm{pH}$} & \multicolumn{3}{|c|}{ Organic C (\%) } & \multicolumn{3}{|c|}{$\mathrm{K}^{+}(\mathrm{ppm})$} \\
\hline & PS 1 & PS 2 & PS 3 & PS 1 & PS 2 & PS 3 & PS 1 & PS 2 & PS 3 \\
\hline \multicolumn{10}{|c|}{ Type of formulation } \\
\hline SP50 & $4.19 \mathrm{~A}$ & $4.07 \mathrm{~A}$ & $4.78 \mathrm{~A}$ & $1.02 \mathrm{~A}$ & $1.17 \mathrm{~A}$ & $1.06 \mathrm{~A}$ & $0.149 \mathrm{AB}$ & $0.063 \mathrm{~A}$ & $0.068 \mathrm{~A}$ \\
\hline SP75 & $4.20 \mathrm{~A}$ & $4.01 \mathrm{~B}$ & $4.77 \mathrm{~A}$ & $1.04 \mathrm{~A}$ & $1.12 \mathrm{~A}$ & $1.05 \mathrm{~A}$ & $0.152 \mathrm{~A}$ & $0.059 \mathrm{~A}$ & $0.068 \mathrm{~A}$ \\
\hline KS50 & $4.22 \mathrm{~A}$ & $3.98 \mathrm{~B}$ & $4.82 \mathrm{~A}$ & $0.97 \mathrm{~A}$ & $1.18 \mathrm{~A}$ & $1.04 \mathrm{~A}$ & $0.136 \mathrm{~B}$ & $0.066 \mathrm{~A}$ & $0.075 \mathrm{~A}$ \\
\hline \multicolumn{10}{|c|}{ Type of application } \\
\hline $0 \mathrm{Mg} \mathrm{ha}^{-1}$ & $4.17 \mathrm{~b}$ & $3.92 \mathrm{~b}$ & $4.61 \mathrm{~b}$ & $1.01 \mathrm{a}$ & $1.10 \mathrm{~b}$ & $0.97 \mathrm{~b}$ & $0.117 \mathrm{c}$ & $0.050 \mathrm{~b}$ & $0.049 \mathrm{~b}$ \\
\hline $\begin{array}{l}7.5 \mathrm{Mg} \mathrm{ha}^{-1} \\
(2.5-2.5-2.5)\end{array}$ & $4.21 \mathrm{a}$ & $3.97 \mathrm{~b}$ & $4.83 \mathrm{a}$ & $0.97 \mathrm{a}$ & $1.17 \mathrm{ab}$ & $1.05 \mathrm{ab}$ & $0.141 \mathrm{~b}$ & $0.062 \mathrm{ab}$ & $0.068 \mathrm{ab}$ \\
\hline $\begin{array}{l}7.5 \mathrm{Mg} \mathrm{ha}^{-1} \\
(5.0-2.5-0)\end{array}$ & $4.21 \mathrm{a}$ & $4.09 \mathrm{a}$ & $4.83 \mathrm{a}$ & $1.05 \mathrm{a}$ & $1.20 \mathrm{a}$ & $1.07 \mathrm{ab}$ & $0.159 \mathrm{a}$ & $0.073 \mathrm{a}$ & $0.087 \mathrm{a}$ \\
\hline $\begin{array}{l}7.5 \mathrm{Mg} \mathrm{ha}^{-1} \\
(7.5-0-0)\end{array}$ & $4.22 \mathrm{a}$ & $4.10 \mathrm{a}$ & $4.88 \mathrm{a}$ & $1.01 \mathrm{a}$ & $1.21 \mathrm{a}$ & $1.09 \mathrm{a}$ & $0.166 \mathrm{a}$ & $0.066 \mathrm{ab}$ & $0.077 \mathrm{a}$ \\
\hline
\end{tabular}

Note: the same numbers followed by different letters in the same treatment group indicated significantly different based on DMRT at 5\% significance level. PS: Planting season.

Table 4. The concentrations of $\mathrm{Ca}^{2+}, \mathrm{Al}^{3+}$, and $\mathrm{Ca}^{2+} / \mathrm{Al}^{3+}$ ratio of upland acid soil amended with biochar during three planting seasons.

\begin{tabular}{|c|c|c|c|c|c|c|c|c|c|}
\hline \multirow{2}{*}{ Treatments } & \multicolumn{3}{|c|}{$\mathrm{Ca}^{2+}$} & \multicolumn{3}{|c|}{$\mathrm{Al}^{3+}$} & \multicolumn{3}{|c|}{$\mathrm{Ca}^{2+} / \mathrm{Al}^{3+}$ ratio } \\
\hline & PS 1 & PS 2 & PS3 & PS 1 & PS 2 & PS 3 & PS 1 & PS 2 & PS 3 \\
\hline \multicolumn{10}{|c|}{ Type of formulation } \\
\hline SP50 & $0.60 \mathrm{~A}$ & $1.00 \mathrm{~A}$ & $1.09 \mathrm{~A}$ & $1.95 \mathrm{~A}$ & $1.69 \mathrm{~A}$ & $1.92 \mathrm{~A}$ & $0.33 \mathrm{~A}$ & $0.61 \mathrm{~A}$ & $0.59 \mathrm{~A}$ \\
\hline SP75 & $0.58 \mathrm{~A}$ & $0.90 \mathrm{~A}$ & $1.18 \mathrm{~A}$ & $2.00 \mathrm{~A}$ & $1.74 \mathrm{~A}$ & $1.78 \mathrm{~A}$ & $0.29 \mathrm{~A}$ & $0.53 \mathrm{~B}$ & $1.32 \mathrm{~A}$ \\
\hline KS50 & $0.56 \mathrm{~A}$ & $0.86 \mathrm{~A}$ & $1.10 \mathrm{~A}$ & $1.98 \mathrm{~A}$ & $1.76 \mathrm{~A}$ & $1.86 \mathrm{~A}$ & $0.30 \mathrm{~A}$ & $0.50 \mathrm{~B}$ & $0.56 \mathrm{~A}$ \\
\hline \multicolumn{10}{|c|}{ Type of application } \\
\hline $0 \mathrm{Mg} \mathrm{ha}^{-1}$ & $0.47 \mathrm{~b}$ & $0.69 \mathrm{~b}$ & $0.77 \mathrm{~b}$ & $2.16 \mathrm{a}$ & $1.96 \mathrm{a}$ & $2.12 \mathrm{a}$ & $0.23 \mathrm{~b}$ & $0.36 \mathrm{c}$ & $0.38 \mathrm{~b}$ \\
\hline $\begin{array}{l}7.5 \mathrm{Mg} \mathrm{ha}^{-1} \\
(2.5-2.5-2.5)\end{array}$ & $0.53 \mathrm{~b}$ & $0.97 \mathrm{a}$ & $1.23 \mathrm{a}$ & $1.98 \mathrm{ab}$ & $1.86 \mathrm{a}$ & $1.68 \mathrm{~b}$ & $0.27 \mathrm{~b}$ & $0.54 \mathrm{~b}$ & $0.73 \mathrm{a}$ \\
\hline $\begin{array}{l}7.5 \mathrm{Mg} \mathrm{ha}^{-1} \\
(5.0-2.5-0)\end{array}$ & $0.61 \mathrm{ab}$ & $0.97 \mathrm{a}$ & $1.24 \mathrm{a}$ & $1.93 \mathrm{ab}$ & $1.58 \mathrm{~b}$ & $1.83 \mathrm{ab}$ & $0.33 \mathrm{ab}$ & $0.62 \mathrm{ab}$ & $0.69 \mathrm{a}$ \\
\hline $\begin{array}{l}7.5 \mathrm{Mg} \mathrm{ha}^{-1} \\
(7.5-0-0)\end{array}$ & $0.70 \mathrm{a}$ & $1.05 \mathrm{a}$ & $1.13 \mathrm{a}$ & $1.84 \mathrm{~b}$ & $1.55 \mathrm{~b}$ & $1.49 \mathrm{~b}$ & $0.39 \mathrm{a}$ & $0.69 \mathrm{a}$ & $0.63 \mathrm{a}$ \\
\hline
\end{tabular}

Note: the same numbers followed by different letters in the same treatment group indicated significantly different based on DMRT at a 5\% significance level. PS: Planting season.

except that in the second planting season (PS 2) (Table 3). Gradual application of biochar-based soil amendment at rate of $7.5 \mathrm{Mg} \mathrm{ha}^{-1}$ in two times of application (5.0-2.5-0 $\left.\mathrm{Mg} \mathrm{ha}^{-1}\right)$ and at individual application (directly at 7.5-0-0 $\mathrm{Mg} \mathrm{ha}^{-1}$ ) increased soil $\mathrm{pH}$ consistently. Application of biochar-based soil amendment, in which the $\mathrm{pH}$ is 7, may increase soil $\mathrm{pH}$, as well as contribute alkaline cations such as $\mathrm{Ca}, \mathrm{K}$ and $\mathrm{Mg}$ to the soil (Table 1). An adequate rate of soil amendment $\left(5.0 \mathrm{Mg} \mathrm{ha}^{-1}\right.$ and $7.5 \mathrm{Mg}^{-}$ ${ }^{1}$ ) is susbtantial to provide productive residual effect to increase soil $\mathrm{pH}$. Furthermore, biochar-based soil amendment application showed no significant different responses on organic $\mathrm{C}$ and exchangeable cations $\left(\mathrm{K}^{+}\right.$and $\left.\mathrm{Ca}^{2+}\right), \mathrm{Al}^{3+}$ and $\mathrm{Ca}^{2+} / \mathrm{Al}^{3+}$ ratios among the three soil amendment formulas (Table 3 and 4). Therefore, the three formulas (SP50, SP75, KS50) can be selected as soil amendment to improve upland acid soil quality at KP Taman Bogo.

The application of three formulas of biocharbased soil amendment on upland acid soil were significantly increased soil $\mathrm{pH}$, organic $\mathrm{C}, \mathrm{K}^{+}, \mathrm{Ca}^{2+}$ 


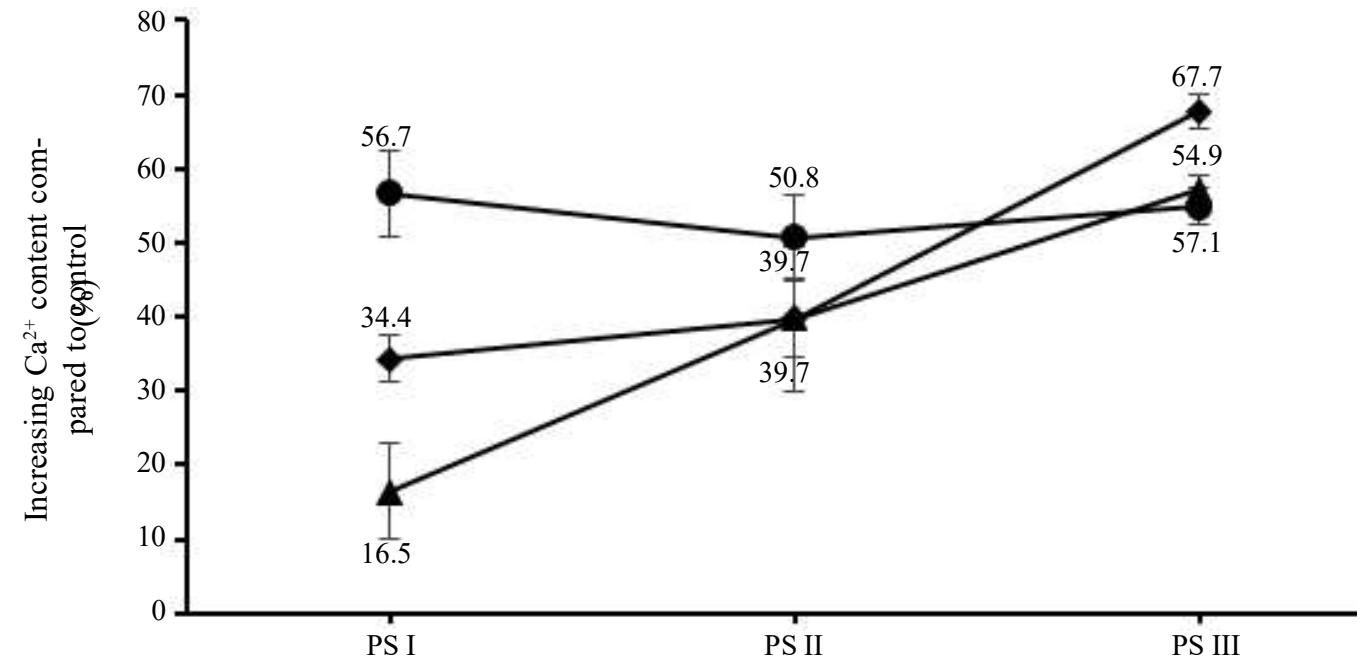

Figure 1. $\mathrm{Ca}^{2+}$ content compared to control $\left(0 \mathrm{Mg} \mathrm{ha}^{-1}\right)$ of upland acid soil amended with biochar during three times planting seasons. $\longrightarrow$ : $2.5-2.5-2.5 \mathrm{Mg} \mathrm{ha}^{-1} ; \multimap: 5.0-2.5-0 \mathrm{Mg} \mathrm{ha}^{-1} ; \multimap-$ 7.5-0.0 $\mathrm{Mg} \mathrm{ha}^{-1}$.

and decreased $\mathrm{Al}^{3+}$ (Table 3 and 4). Table 1 suggested that the application of soil amendment formulas at rates of $7.5 \mathrm{Mg} \mathrm{ha}^{-1}$ can supply $\mathrm{K}^{+}$and $\mathrm{Ca}^{2+}$ during three planting seasons, namely 48.2$61.1 \mathrm{~kg} \mathrm{ha}^{-1}$ and 80.4-101.3 $\mathrm{kg} \mathrm{ha}^{-1}$, respectively. In addition, biochar capability to increase nutrient retention in soil can reduce nutrient leaching from soil (Widowati et al. 2014), and biochar capability to load base cations can increase soil $\mathrm{pH}$ and decrease $\mathrm{Al}^{3+}$ (Cornelissen et al. 2005; Mukherjee and Zimmerman 2013).

The different application ways, i.e. single and gradual applications, resulted in different effectiveness in increasing soil $\mathrm{pH}$, organic $\mathrm{C}$ content, and exchangeable cations $\left(\mathrm{K}^{+}\right.$and $\left.\mathrm{Ca}^{2+}\right)$. However, early application of high dose $\left(5.0 \mathrm{Mg} \mathrm{ha}^{-1}\right.$ and 7.5 $\mathrm{Mg} \mathrm{ha}^{-1}$ ) showed consistent response during the three planting seasons. Table 4 proposed some soil chemical properties affecting soil acidity, thus, it has been confirmed that individual application at $7.5 \mathrm{Mg} \mathrm{ha}^{-1}$ increased the content of $\mathrm{Ca}^{2+}$ and $\mathrm{Ca}^{2+} / \mathrm{Al}^{3+}$ ratio and decreased $\mathrm{Al}^{3+}$ content. The results indicated that one time application of $7.5 \mathrm{Mg} \mathrm{ha}^{-1}$ showed good response on soil chemical properties improvement, therefore, the residual effect of biochar-based soil amendment effectively improved soil productivity.

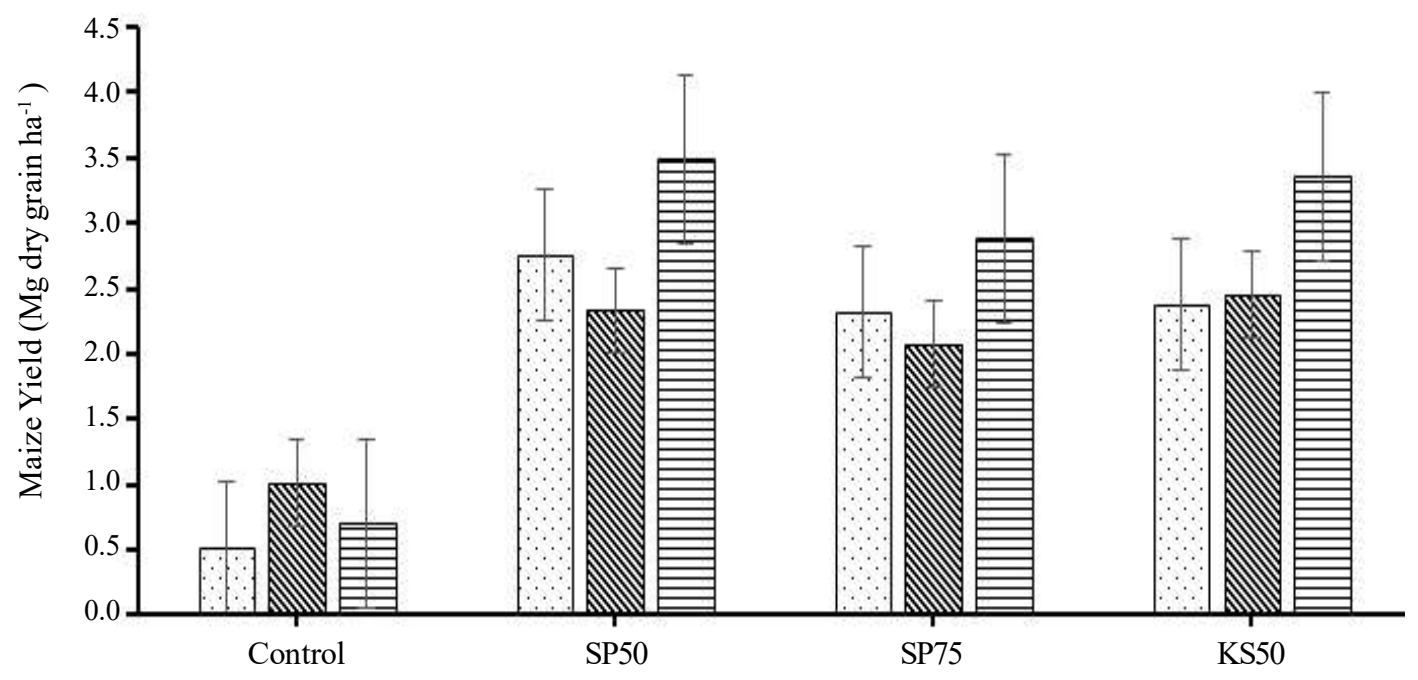

Figure 2. Yield of maize grown on upland acid soil amended with biochar during three planting seasons. $\square$ : Planting season 1; $\mathbb{N}$ : Planting season 2; 目: Planting season 3. 
J Trop Soils, Vol. 24, No. 1, 2019: 33-41

Table 5. Maize yield during three planting seasons due to application of biochar-based soil amendment on upland acidic soil at KP Taman Bogo, East Lampung.

\begin{tabular}{llclclc}
\hline \multirow{2}{*}{ Treatments } & \multicolumn{2}{c}{ PS 1 } & \multicolumn{2}{c}{ PS 2 } & \multicolumn{2}{c}{ PS 3 } \\
\cline { 2 - 7 } & Dry grain & $\%^{1}$ & Dry grain & $\%^{1}$ & Dry grain & $\%^{1}$ \\
\hline $0 \mathrm{Mg} \mathrm{ha}^{-1}$ & $1.54 \mathrm{~b}$ & - & $1.56 \mathrm{~b}$ & - & $1.45 \mathrm{~b}$ & - \\
$7.5 \mathrm{Mg} \mathrm{ha}^{-1}(2.5-2.5-2.5)$ & $2.45 \mathrm{ab}$ & 59.1 & $2.83 \mathrm{a}$ & 81.4 & $3.35 \mathrm{ab}$ & 131.0 \\
$7.5 \mathrm{Mg} \mathrm{ha}^{-1}(5.0-2.5-0)$ & $3.36 \mathrm{a}$ & 118.2 & $3.20 \mathrm{a}$ & 105.1 & $3.71 \mathrm{a}$ & 155.9 \\
$7.5 \mathrm{Mg} \mathrm{ha}^{-1}(7.5-0-0)$ & $4.17 \mathrm{a}$ & 170.8 & $3.29 \mathrm{a}$ & 110.9 & $4.14 \mathrm{a}$ & 185.5 \\
\hline
\end{tabular}

Note: the same numbers followed by different letters in the same treatment group indicated significantly different based on DMRT at a 5\% significance level. PS: Planting season. ${ }^{1)}$ Increasing of dry grain compared to control $\left(0 \mathrm{Mg} \mathrm{ha}^{-1}\right)$.

Figure 1 showed that single and gradual applications of biochar-based soil amendment during three planting seasons resulted in different effectiveness in increasing $\mathrm{Ca}^{2+}$ content compared to control. The 3 times of application in 3 planting seasons (2.5-2.5-2.5 $\mathrm{Mg} \mathrm{ha}^{-1}$, each season) increased $\mathrm{Ca}^{2+}$ gradually, namely $16.5 \%$ (PS 1), $39.7 \%$ (PS 2), and $57.1 \%$ (PS 3) compared to control. However, one time application (7.5-0-0 Mg $\mathrm{ha}^{-1}$ ) consistently increased $\mathrm{Ca}^{2+}$ to $56.7 \%$ (PS 1 ), $50.8 \%$ (PS 2) and $54.9 \%$ (PS 3), whereas gradual application in two times at 3 planting seasons (5.0$\left.2.5-0 \mathrm{Mg} \mathrm{ha}^{-1}\right)$ is in the between the previous two application ways. Hence, application at once (7.5$\left.0-0 \mathrm{Mg} \mathrm{ha}^{-1}\right)$ in the first planting season was more beneficial to decrease soil acidity in upland acid soil of KP Taman Bogo due to high ability to reduce $\mathrm{Al}^{3+}$ toxicity.

\section{Maize Yield}

Yield of maize applied with biochar-based soil amendment were significantly higher than control $\left(0 \mathrm{Mg} \mathrm{ha}^{-1}\right)$ that only produced $<1.0 \mathrm{Mg} \mathrm{ha}^{-1}$. Soil amendment application is necessary because maize will not grow optimally without soil amendment application as shown in Figure 2. Maize yield (in dry weight of grain) after biochar-based soil amendment application namely 3.47-4.13 $\mathrm{Mg} \mathrm{ha}^{-1}$ (PS 1); 3.11-3.67 $\mathrm{Mg} \mathrm{ha}^{-1}$ (PS 2); and 4.32-5.23 $\mathrm{Mg} \mathrm{ha}^{-1}$ (PS 3), which increased 291\% during three planting seasons. The application of SP50 and KS50 formulas produced more stable dry weight of grain (Figure 2), which indicated that the proportion of $50 \%$ biochar in the formula is better compared to $75 \%$ of biochar proportion. Compost addition in the soil amendment formulas provides benefits for plant growth, in which compost increased nutrient content in the formulas compared to only biochar application (Nurida et al. 2013), while biochar as porous material will retain more nutrients (Nurida et al.
2014; Hale et al. 2013) and water (Sutono and Nurida 2012; Shaaban et al. 2013). The response of crop yield due to soil amendment application showed that the three formulation were potential to be applied in the upland acidic soil at KP Taman Bogo to support maize productivity.

The application way of the soil amendment gradually or at once in the first planting season resulted in no significant different on crop yield (Table 5), nevertheless the yield was very significantly different compared to that from control plot, especially for the application of 5.0-2.5-0 kg $\mathrm{ha}^{-1}$ and 7.5-0-0 $\mathrm{Mg} \mathrm{ha}^{-1}$ (high rates at first season). Both formulations consistently produced higher yield, namely 3.36 and $4.17 \mathrm{Mg} \mathrm{ha}^{-1}$ in the first season, 3.20 and $3.29 \mathrm{Mg} \mathrm{ha}^{-1}$ in the second season, 3.71 and $4.14 \mathrm{Mg} \mathrm{ha}^{-1}$ in the third season. The increase of crop yield was very significant, i.e. up to $105.1 \%$ $185.5 \%$. Gradual application also generated improvement on crop yield during three planting seasons up to $131.0 \%$. Table 5 showed that the recommended application way of biochar-based soil amendment is the application of high dose in the first season due to its significant increase on crop productivity. Crop yield due to application of biocharbased soil amendment in the study was about 2.454.17 $\mathrm{Mg} \mathrm{ha}^{-1}$ per season, which is considered below the potential yield of Bisma variety, i.e. 7.0-7.5 Mg ha $^{-1}$ (Aqil et al. 2012). However, the upland acidic soil in the study location has experienced degradation of its quality, so thus the application of biochar-based soil amendment has been confirmed its potential to improve maize productivity.

\section{CONCLUSIONS}

During three planting seasons, the application of three different types of biochar-based soil amendment formulas did not affect the soil physical properties (BD and AWP), soil chemical properties $\left(\mathrm{pH}\right.$, organic $\mathrm{C}, \mathrm{K}^{+}, \mathrm{Ca}^{2+}$ and $\left.\mathrm{Al}^{3+}\right)$ and maize yield, 
but they were significantly different compared to those in the control treatment (without biochar application). Three biochar formulations (SP50, SP75, and KS50) increased the dry weight of grain up to $291 \%$ (3.11-5.23 $\mathrm{Mg} \mathrm{ha}^{-1}$ ) during three planting seasons. The application way of one time during three planting seasons $\left(7.5-0-0 \mathrm{Mg} \mathrm{ha}^{-1}\right)$ was more effective and consistent in increasing AWP, soil chemical properties, and maize yield compared to the gradual application.

\section{ACKNOWLEDGEMENTS}

We thank the Indonesian Soil Research Institute for providing fund for this research, Ir. Yoyo Soelaeman, M.S. for peer-review on the manuscript and to all staff of Taman Bogo Research Station for their valuable assistance in the field.

\section{REFERENCES}

Agegnehu G, P N Nelson, M I Bird. 2016. Crop yield, plant nutrient uptake and soil physicochemical under organic soil amendments and nitrogen fertilization on Nitisols. Soil Till Res 160: 1-3.

Aqil M, C Rapar dan Zubachtirodin. 2012. Deskripsi Varietas Unggul Jagung. Pusat Penelitian dan Pengembangan Tanaman Pangan. Badan Penelitian dan Pengembangan Pertanian. Kementerian Pertanian. 141 halaman.

Asai H, B K Samson, H M Stephan, K Songyikhangsuthor, K Homma, Y Kiyono, Y Inoue, T Shiraiwa, T Horie. 2009. Biochar amendment techniques for upland rice production in Northern Laos 1. Soil physical properties, leaf SPAD and grain yield. Field Crops Res 111:81-84.

Atkinson CJ, JD Fitzgerald and NA Hipps. 2010. Potential mechanisms for achieving agricultural benefits from biochar application to temperate soils: a review. Plant Soil 337:1-18.

Basso AS, FE Migues, AL David, H Robert, M Westgate. 2013. Assesing potential of biochar for increasing water holding capacity of sandy soils. $G C B$ Bioenergy 5:132-143.

Cornelissen G, J Hafika, JR Parsons and O Gustafsson. 2005.Sorption to Black Carbon of Organic Compounds with Varying Polarity and Planarity. Envinron Sci Technol 39: 3688-3694

Cornelissen G, Jubaedah, NL Nurida, SE Hale, V Martinsen, L Salvani, J Mulder. 2018. Fading positive effect of biochar on crop yield and acidity during five growth seasons in an Indonesian Ultisol. Sci Total Environ 634:561-568. http:// doi.org/10.1016/j.scitotenv.2018.03.380.

Crane-Droesch A, S Abiven, S Jeffrey and MS Torn. 2013. Heterogeneous global crop yield response to biochar: a meta-regression analysis. Environ Res Lett 8: 1-8. doi: 10.1088/1748-9326/8/4/044049.
Dariah A, NL Nurida and Sutono. 2013. The effect of biochar on soil quality and maize production in upland in dry climate region. In: Proceeding $11^{\text {th }}$ international Conference the East and Southeast Asia federation of Soil Science Societies. Bogor, Indonesia

Haefele SM, Y Konboon, W Wongboon, S Amarante, AA Maarifat, EM Pfeiffer and C Knoblauch. 2011. Effects and fate of biochar from rice residues in ricebased systems. Field Crop Res 123: 430-440.

Hale SE, V Alling, V Martinsen, J Mulder, GD Breedveld and $G$ Cornelissen. 2013. The sorption and desorption of phosphate-P, ammonium-N and nitrate-N in cacao shell and corn cob biochars. Chemosphere 91: 1612-1619.

Jeffery S, FGA Verheijen, M van der Velde and AC Bastos. 2011. A quantitative review of the effects of biochar application to soil on crop productivity using metaanalysis, Agric Ecosyst Environ 144: 175-187.

Kammann CI, HP Schmidt, N Messerschmidt, S Linsel, D Steûens, C Müller, HW Koyro, P Conte and S Joseph. 2015. Plant growth improvement mediated by nitrate capture in co-composted biochar. Scientific Report 5:11080.

Kammann CI, B Glaser and HP Schmidt. 2016. Combining biochar and organic amendments.In: Shackley S, G Ruysschaert, K Zwart and B Glaser (eds), Biochar in European Soils and Agriculture: Science and Practice. 1. Routledge, London, p. 136-160.

Laird DA, P Fleming, DD Davis, R Horto, BQ Wang and DL Karlen. 2010. Impact of biochar amandement on quality of typical Midwestern Agricultural Soil. Geoderma 158: 443-449

Maswar and Y Soelaeman. 2016. Effects of organic and chemical fertilizer inputs on biomass production and carbon dynamics in a maize farming on Ultisols. AGRIVITA J Agric Sci 38: 133-141.

Mukherjee A and AR Zimmerman. 2013. Organic carbon and nutrient realease from a range of laboratoryproduced biochars. Geoderma 163:247-255.

Nurida NL, A Dariah and A Rachman. 2009. Kualitas Limbah Pertanian Sebagai Bahan Baku Pembenah Berupa Biochar untuk Rehabilitasi Lahan. Prosiding Seminar Nasional dan Dialog Sumberdaya Lahan Pertanian.p. 209-215

Nurida NL, A Dariah and A Rachman. 2013. Peningkatan kualitas tanah dengan pembenah tanah biochar limbah pertanian. J tanah dan Iklim 37: 69-78.

Nurida NL. 2014. Potensi pemanfaatan biochar untuk rehabilitasi lahan kering di Indonesia. Jurnal Sumberdaya Lahan Edisi khusus Karakteristik dan Variasi Sumberdaya Lahan Pertanian: 57-68

Nurida NL, A Dariah dan A Rachman. 2015. Pembenah Tanah Alternatif untuk Meningkatkan Produktivitas Tanah dan Tanaman Kedelai di Lahan Kering Masam. J Tanah dan Iklim 39: 47-56.

Quin PR, AL Cowie, RJ Flavel, BP Keen, LM Macdonald, SG Morris, BP Singh, LM Young and L Van Zwieten. 2014. Oil maillee biochar improves soil structural properties= a study with X-ray micro-CT. Agric Ecosyst Environ 191, 142-149. 
Rochayati S and A Dariah. 2012. Pengembangan Lahan Kering Masam; Peluang, Tantangan dan Strategi serta Teknologi Pengelolaan. In: A Dariah, B Kartiwa, N Sutrisno, K Suradisastra, M Sarwani, H Soeparno and E Pasandaran (eds). Prospek Pertanian Lahan Kering Dalam Mendukung Ketahanan Pangan. Jakarta: IAARD Pres, p.187-204. (in Indonesian).

Schmidt HP, B Pandit, V Martinsen, G Cornelissen, P Conte and C Kammann. 2015. Fourfold increase in pumpkin yield in response to low-dosage root zone application of urine-enhanced biochar to a fertile tropical soil. Agriculture 5: 723-741.

Schulz H, G Dunst and B Glaser. 2013. Positif effect of composted biochar on plant growth and soil fertility. Agron Sustain Dev 33: 817-827.

Schulz H, G Dunst and B Glaser. 2014. No effect level of co-composted biochar on plant growth and soil properties in a greenhouse experiment. Agronomy 4:34-51

Shaaban A, SM Se, NMM Mitan and MF Dimin. 2013. Characterization of biochar derived from rubber wood sawdust though slow pyrolysis on surface porosities and functional groups. Procedia Engineering 68:365-371. https://doi.org/10.1016/ j.proeng.2013.12.193

Singh U, PW Wilkens, J Henao, SH Chien, DT Hellums and LL Hammond. 2003. An expert system for estimating agronomic effectiveness of freshly applied phosphate rock. In: SSS Rajan and SH Chien (eds). Direct application of phosphate rock and related technology-latest developments and practical experiences. Proc International Mtg., Kualalumpur, Malaysia.16-20July 2001. IFDC-SP37.IFDC. pp. 214-224.

Soelaeman Y and U Haryati. 2012. Soil Physical Properties and Production Of Upland Ultisol Soil As Influenced By Manure Application And $\mathrm{P}$ Fertilization. AGRIVITA J Agric Sci 34: 136-143. ISSN: 0126-0537.
Soelaeman Y, Maswar and U Haryati. 2017. Pembenah tanah dan mikroba pelarut $\mathrm{P}$ untuk meningkatkan efektifitas pupuk NPK pada jagung di lahan kering masam. Penelitian Tanaman Pangan 1: 45-52.

Spokas KA, KB Cantell, JM Novak, DW Archer, JA Ippolito, HP Collin, AA Boateng, IM Lima, MC Lamb, AJ Mc Aloon, RD Lentz and KA Nichols. 2012. Biochar: A synthesis of its agronomic impact beyond carbon sequestration. J Environ Qual 41: 973-989.

Sukartono dan WH Utomo. 2012. Peranan biochar sebagai pembenah tanah pada pertanaman jagung di tanah lempung berpasir (sandy loam) semiarid tropis Lombok Utara. J Penelitian Ilmu-Ilmu Kealaman: Buana Sains Tribhuana Press. 12: 91-98.

Sutono dan NL Nurida. 2012. Kemampuan biochar memegang air pada tanah bertekstur pasir. $J$ Penelitian Ilmu-Ilmu Kealaman: Buana Sains. Tribhuana Press. 12: 45-52.

Suwardji, Sukartono dan WH Utomo. 2012. Kemantapan agregrat setelah aplikasi biochar di tanah lempung berpasir pada pertanaman jagung di lahan kering Kabupaten Lombok Utara. J Penelitian Ilmu-Ilmu Kelaman: Buana Sains. Tribhuana Press. 12: 61-68.

Tan KH. 1993. Principle of Soil Chemistry. Marcel Dekker Inc. New York.

Widowati, WH Utomo and Asnah. 2014. The Use of Biochar to Reduce Nitrogen and Potassium Leaching from Soil Cultivated with Maize. J Degraded and Mining Lands Management 2: 211-218.

Wigena IGP and Andriati. 2016. Sistem usahatani berkelanjutan berbasis dinamika unsur hara pada lahan kering masam. J Sumberdaya Lahan 10: 11-24.

Zhu Q, X Peng, T Huang, Z Xie and NM Holden. 2014. Effect of biochar addition on maize growth and nitrogen use efficiency in Acid Red Soil. Pedospere 24: 600-708. 